\title{
Education Communication in the English Learning Process
}

\author{
Jetas Rahman ${ }^{1}$, Afrizal ${ }^{2}$, Ernita Arif $^{3}$ \\ ${ }^{1,2,3}$ Andalas University, Padang, Indonesia \\ Email: jetasrahman@gmail.com
}

\begin{abstract}
This research was conducted with the aim of analyzing instructional communication between teachers and students in learning English and the obstacles faced by teachers and students in achieving learning communication objectives located at SMPN 25 Solok Selatan. This research uses qualitative research. Determination of informants by means of purposive sampling, research data obtained through in-depth interviews, observation, and documentation. Data processing techniques using the model of Miles and Huberman analysis and data validity with triangulation. The results showed that in the learning or instructional communication process: (1) communicators were still dominated by teachers while many students were still passive; (2) messages are arranged and designed by teachers based on the applicable curriculum taking into account the different backgrounds of students; (3) the method used is the lecture, demonstration, discussion, and question and answer method; and (4) feedback in the communication process is done directly by students both verbally and nonverbally. Barriers that occur in the learning communication process include the use of language by communicators that are less understood by students, the limited media used and the lack of motivation of students in learning English.
\end{abstract}

Keywords: Educational Communication, Learning Process, English.

\section{A. INTRODUCTION}

Communication and education are two interrelated things, the purpose of education can be achieved if communication goes well and smoothly. Education has several variables, one of which is instructional or learning. Learning involves many components in it such as teachers, students, media and so on. The learning process is a reality of communication and every communication realized or not, must have their respective goals. Communication in the learning process has a specific purpose which is to convey educational messages. The messages are mostly conveyed in the learning process in class.

This communication activity is contained in all learning processes. One very important component in the process is the delivery of educational messages. Educational messages communicated by the teacher in the learning process are supported by the method and communication skills of a teacher. The achievement of the message in the communication process in learning we can know one of them from the achievement of the objectives of the learning appropriately. This we can know from the feedback or feedback given by the communicant, this feedback will be very useful to a messenger in 
the form of information. This information will be useful for a teacher to evaluate the communication process that has occurred.

The process of sending messages in the learning process involves the teacher and students, the purpose of the message will be successful if the delivery of the teacher to students can be delivered and received well and vice versa. The success of delivering this message is very important because it is related to the purpose of education, one of which is to educate the nation. The destruction of the world of education will certainly greatly affect the sustainability of a nation because education is basically an attempt to educate the nation. Initial education is received by someone starting from the family and continued at formal and non-formal educational institutions. In this study, researchers will focus on learning foreign languages informal educational institutions, namely Junior High Schools. This is because English is only taught evenly at this level whereas at the elementary level English lessons are no longer compulsory subjects.

The success of communication in learning cannot be separated from the role of a teacher as an educator because communication is one of the essential competencies for a teacher, as said by Zlatik, Bjekic, Marinkovic, and Bojovic "Communication competence, as a system of knowledge, skills, abilities, motivational disposition, attitudes and properties in teaching communication and social interaction, is the essential competence of teachers ". So, as a teacher, communication competence is the basis for the teacher's professional actions to achieve effective learning communication, which is more emphasized on the active empowerment of students.

In learning English the teacher is not only required to be proficient in English but how to communicate in the language. This means, language learning is not just knowing the language but how students can use the language to communicate. Especially for new English learning, it is taught at the Secondary School level evenly so that for some students this learning becomes a new thing even though there are some students who have known English since Elementary School if they have studied at a course or tutoring. Therefore, teacher communication competence is very important in this regard.

But the problem can arise either from the teacher as a communicator, students as a communicant or vice versa or can also be caused by a system of language learning itself, as described by Akbari (2015: 400) "The problems fall into seven categories which constitute five important components of any education system (students, teachers, materials, teaching methods, and evaluations) and two other subcomponents (curriculum and policy) which are closely interrelated".

Language learning becomes interesting because we are not only focused on the use of foreign languages themselves but also on receiving messages using that language when communicating. Siswandi (2006: 24) states the importance of the function of language as a means of communication and thinking tools seen in language subjects ranging from basic education to tertiary education. 
English lessons have been taught starting from junior high school to senior high school and even up to university level in Indonesia but this does not guarantee all students in Indonesia can speak English fluently even though they have studied it for more than six years. In learning English, students are required to master four language competencies, namely listening, speaking, reading, and writing. However, the tendency that is carried out in schools only focuses on reading comprehension skills or only on one competency so opportunities to understand other competencies are limited besides the use of English to communicate very rarely applied in schools.

South Solok Regency is one of the districts that split from Solok Regency in 2004, this of course also has an impact on all government and education systems. Even though it has been in bloom for almost 15 years without making the education system develop rapidly, the fact is according to Widya Sri Wahyuni, M. Pd, one of the academics in South Solok, poor communication, low motivation, and limited facilities and infrastructure are still factors hindering the development of education in the district. Solok Selatan (Interview on 01 February 2019).

This regency was chosen as a research location with the consideration of the lack of facilities and infrastructure that supports English learning and is still classified as a low district position. South Solok on the final exam which is ranked 17th out of 19 districts (sumbar.com). In addition, in several areas in the district. Solok Selatan English lessons are still considered less important by students to be studied so that the process of sending messages is not running as it should.

South Solok Regency has 38 Junior High Schools, out of the 38 schools the researchers chose South Solok 25 Middle School as a research site because South Solok 25 Middle School is one of the schools that have achievements such as being one of 53 schools that are designated as provincial Adiwiyata schools in 2018 and several times ranked first in the UN in South Solok Regency as in the 2015/2016 and 2016/2017 school year and in 2018 this school was ranked third in the province of West Sumatra for the UNKP score.

The first assumption when researchers choose this school is that this school has a good communication process in learning so that the message delivered can be well received by students. In addition, the location of the school is far from the center of the district capital but has good achievements, of course, interesting to study.

Junior High School has many subjects taught. However, in this study, the researchers only focused on the process of learning a foreign language namely English. This is because in general education in Indonesia is still oriented towards good grades, without regard to the essential goals of each learning. Especially in language learning that has an essential goal, namely mastery of the language itself, especially in receptive skills (the ability to listen and read) and productive skills (the ability to write and speak). So that the goal so that after learning English students can use English to communicate can not yet be achieved. 
The above also occurs at SMPN 25 Solok Selatan, according to some English teachers in this school lack of student motivation in learning a foreign language because it is considered difficult, the learning process is boring, fear of making mistakes in using a foreign language also causes the use of English in communication less maximum. The problem does not only come from technical learning, because according to the English teacher the problem also comes from psychological students such as not having the courage to speak in English for fear of being ridiculed by his friends (interview with an English teacher at SMPN 25 Solok Selatan on 17 December 2018 ).

This research is interesting to study because high achieving schools generally have a good learning communication process. But in this school, most learning communication is still one-way and the media used are still very limited, but on the other hand, this school has a good performance and a pretty good final exam score. Especially in learning English, this school also won a storytelling contest at the district level.

The communication process in learning English involves teachers, students, teaching materials, media and also feedback. However, the process of learning English in this school has not been running as it should, without the achievement of the core objectives of learning English. English is a learning that is expected to make students able to speak English well and use it as a tool to communicate. However, this has not been achieved in this school,

The use of English as an oral communication tool in learning has not been used to its full potential. Whereas the communicative approach to learning English emphasizes the ability to speak as said by Yusof and Halim (2014: 472) "... it is clear that the communicative approach puts a lot of emphasis on speaking skills. This is the line with the hypothesis that teachers of a second language teach the target language more effectively through teaching and participating in meaningful classroom communication with students. students who can indeed speak in English.

\section{B. LITERATURE REVIEW}

Communication comes from the Latin "communis" or "commun" in English which means the same. Communicating means trying to achieve common meaning, commonness. Through communication, we try various information, ideas or attitudes with other participants. The main obstacle in communication is that there are often misunderstandings of different meanings of the same symbol. Therefore, communication should be considered as an activity where no action or expression is given full meaning unless identified by the communication participant involved (Bungin, 2009:257).

Cangara (2011:20), says communication is an exchange of information (messages), where there is an exchange of information (messages) that wants a change of attitude, and behavior and togetherness in creating a mutual understanding of the people involved in the communication process. The communication process is an activity that takes place dynamically. That is, the elements that exist in active mobile communica- 
tion, dynamic, and not static (Cangara, 2011:51). In addition, Suprapto (2011:7) said that the communication process is every step from creating information to being understood by the communicant.

Educational communication can be interpreted as communication that occurs in an educational setting. Thus, educational communication is the process of traveling messages or information that penetrates the field or events of education. Here communication is no longer free or neutral but is controlled and conditioned for educational purposes (Nuaim, 2011: 5).

According to Sanaky (2011:9) the components contained in learning as communication are: (a) the teacher can carry out his function as a messenger (communicator), (b) learners as recipients of messages (communicants), (c) subject matter as messages, (d) learning aids as learning channels or media, and (e) there are other factors in learning that are feedback that manifests in the form of questions, answers, and opinions, both from the learner and from the instructor.

The concept of teaching provides indicators that teachers are more studentcentered. Achieving an optimal result, highly dependent on the activities of students or students themselves. A teaching and learning process is said to be good if the process can generate effective learning activities. Teaching that is said to work well is based on the recognition that it is essentially a meaningful process, not something that takes place purely mechanically, not just routine (Sadirman, 2007:47).

In this meaningful process, the meaning of a message is very important. The message will be meaningful if there is no single meaning between the messages conveyed by someone interpreting it, the feedback given can vary and this will affect the success of the communication. the effects of communication vary, namely cognitive effects (knowledge), affective (attitude), and conative (behavior) (Vardiansyah, 2004:110). Cognitive effects are the first effects that arise aimed at giving a message so that the communicant knows about the message conveyed to him, can be a change in perception or change in opinion. Affective effects are effects that arise at the level of feeling while the conative effect after someone knows and feels a message, the next stage is that they will take certain actions on a message in the form of both physical and non-physical.

\section{METHOD}

This study uses qualitative research methods, which have definitions in the form of research that intends to understand phenomena about what is experienced by research subjects, for example, behavior, perception, motivation, actions, and others as a whole and by means of descriptions in the form of words and language, in a special natural context and by utilizing various natural methods (Moleong, 2011:6).

The study was conducted in South Solok Regency, West Sumatra Province, which was carried out from February to April 2019. The informants in this study were two English teachers and eight students. Data collected in this study consisted of prima- 
ry data and secondary data. Data collection in this study was preceded by secondary data collection, especially concerning theories related to research. Primary data is data taken directly from research subjects by conducting in-depth interviews, observations and documentation studies.

Data analysis is the process of collecting data and sorting them in patterns and data collection. Bungin argued that data analysis is a very important part of the scientific method because in the analysis of the data it can be given meaning and meaning that is useful for solving research problems.

The data analysis technique uses Miles and Huberman's data analysis which suggests that the activities in qualitative data analysis are carried out interactively and continue continuously until completion so that the data is already saturated (Sugiyono, 2016:246). The stages of Miles and Huberman's data analysis are as follows:

1. Data Reduction is defined as the process of analyzing data by sharpening, selecting, focusing, discarding, organizing data. In this data reduction, the data reduced by the researcher is the data obtained from observations, interviews, and documentation. All data is sorted and marked so that researchers can focus on data related to the learning communication process.

2. Making narrative text as a data model, this narrative text contains a collection of information about the communication process of teachers and students in improving foreign language learning.

3. Conclusion Withdrawal. Furthermore, based on the data that has been reduced and made narrative text, conclusions are drawn about the phenomena encountered in the field regarding the communication process of teachers and students in improving foreign language learning.

\section{RESULTS AND DISCUSSION}

In this study, the learning communication process refers to the components of communication in the learning context, namely communicators, messages, channels, communicants and feedback. The main elements of communication that refer to learning communication are:

1. Communicators, in this study, are teachers whose tasks relate to learning plans, the selection of teaching materials, explaining and explaining learning. However, in certain situations communicators can also be students.

2. The message, wherein this study are organized teaching materials, teaching materials, and learning objectives.

3. Channels in this study are learning tools or media. Which are verbal and nonverbal techniques, learning activities and learning aids, print and non-print media, and learning resources?

4. Communicators are students related to the response to teaching materials, interpretation of teaching materials and behavior change. However, in certain situa- 
tions, the teacher can also become a communicant.

5. Feedback, delivered by students who communicate with teachers, students who ask for an explanation, students who agree, and students who accept or reject.

The communication process is a process that cannot be separated from the learning process. This process takes place during the learning process also takes place. The communication process in learning English at SMPN 25 Solok Selatan takes place in the classroom and outside the classroom. However, this communication process is classified as formal and informal, such as communication outside the classroom which is usually limited to greetings in English.

Communicator is someone who plays a role in delivering messages, in the learning process of English the dominant communicator is the teacher. This is due to a large number of students who are passive during the learning process. However, this does not rule out the possibility of students also acting as communicators at a certain time.

The teacher as a communicator is not only a person who conveys messages about science and skills, but also educates and guides students to become human beings who have knowledge, skills and good behavior. A teacher who is able to teach and educate well means having a desire to make changes in the attitudes, behaviors, opinions and social roles of their students so that the objectives of their educational communication can be carried out properly.

As an English teacher communicator at SMPN 25, Solok Selatan usually begins activities in the learning process by greeting students first and then proceeding to ask questions relating to previous learning. So before starting on the new material the teacher first reviews the previous material, this serves to check whether the learning message has been conveyed. Usually, if there are still many questions from students the teacher will repeat the learning again.

The process of learning English usually takes place twice a week in each class and on Saturdays this school usually conducts self-development. One of her development is English, the teacher usually acts as an instructor and manages it.

In addition to the compulsory learning process, English is also taught on selfdevelopment but the learning process is different from the compulsory lessons, on the self-development the members come from all classes and of course this affects the teacher's method as a communicator in their learning because they have very different background knowledge. In addition, the curriculum used is also not focused on the English learning standard but depends on each teacher.

The teacher as a communicator will pay attention to the communicant first, even though in the learning process the message to be delivered has already been stipulated in the lesson plan but in the process, it must still be adjusted to the background of the students. Likewise in this school, the English teacher adjusts the vocabulary used with the background of the students. Aside from being a communicator, it turns out the teacher also acts as a communicant, especially when the storytelling material is because 
in this learning the active role is indeed the students so the teacher only comments when evaluating it.

The message is something that is very important in communication, related to messages in the learning communication process, so this is slightly different from communication messages in general because messages in the learning process are more tied to the material delivered. According to Wilbur Schramm in Effendi $(2008,32)$ the message must be designed and delivered in such a way that the message can influence and attract the attention of the intended target, the message must arouse the personal needs of the communicant, and the message must suggest a way to obtain those needs.

Characteristics of messages clearly have an impact on the communication process. Different people receiving the same message might interpret conclusions differently, give different meanings and react differently. However, the characteristics of a message can have a powerful effect, although it may not be explained by an explanation based on the direct and simple cause.

The method of delivering messages becomes a very important aspect of the learning communication process. However interesting material a message but if the method of delivering the message is not right then the message will not arrive at the communicant in accordance with the purpose of the communication. In this case, the South Solok 25 Middle School teacher delivered a message using the Lecture Method, demonstration, discussion and question, and answer methods.

Every beginning there will be an English teacher learning activity at SMPN 25 South Solok preparing a learning message design that is learning material. Planning is one of the most important before learning activities are carried out so that the message conveyed can be received by the communicant properly. A teacher must be able to plan in the form of lesson plans in advance.

In the process of planning the implementation of communication, the English teacher at SMPN 25 Solok Selatan determines how the contents and objectives are in the communication. Communication in the teaching and learning process begins with the instructor because the instructor is the person who conveys the message or information first before being responded by students. However, it is also possible for students to prepare what will be learned because teachers usually provide syllabi at the beginning of the learning semester. In the process of communication education, teachers are usually the most dominating people in learning activities even though in the latest curriculum the more active students are required to be students, but in this school, they are still dominated by teachers.

Based on observations that researchers do each different learning material also results in different ways of determining the contents and objectives in the implementation of communication. Translation of the learning material is done by the teacher verbally and in writing. In this stage the learning design is made specifically by the teacher but is still being discussed in the MGMP by the teacher, this is so that the delivery of 
content and the objectives of learning English effectively.

In general, the content and learning objectives are to teach students to understand English starting from writing to pronunciation in English. Before teaching in class, the teacher first makes a concept of the material to be delivered. The concept is in the form of a Learning Implementation Plan (RPP). In the formulation of the RPP, the teacher firstly formulates the objectives to be achieved. After that proceed to determine the appropriate methods, tools and learning materials used for teaching. Before conducting learning activities, the teacher conducts an assessment of behavior starting with understanding the situation and conditions of the students. The students come from different backgrounds and also different cultures due to the large number of transmigration residents in this Nagari. Therefore teachers must understand their initial situation and conditions first. In the implementation of learning, instructors must also know in advance the initial abilities that have been owned by students.

The selection and use of media are very important also for teachers in conveying the message of learning. Generally, the media used in the learning process are print media such as books and are also supported by utilizing the surrounding environment as real media in communicating.

Based on field observations, there are several types of communication used by English teachers in this school, including interpersonal communication. Interpersonal communication is communication that occurs between the communicant with the communicator face-to-face and immediately occurs feedback. This interpersonal communication is seen in the classroom and outside the classroom. In addition, when outside the classroom when students learn on their own and get complicated, the students ask the teacher directly and the teacher explains the material asked by students. This interpersonal communication takes place in the learning of English that takes place at this school, with this communication the relationship between the teacher and students becomes very good. This communication is very helpful for students who have difficulties in accepting or understanding English subject matter because the instructor can get closer and know the condition of the students. Thus students like and understand the material being taught.

In addition, there is also communication that is group, group communication is communication that takes place between members of a group. This group communication is also used in English learning programs at this school. The researcher's observations are when the teacher and students listen to a song to practice listening and when the teacher explains the material it appears that the activity is carried out in groups or together. Activities that researchers encounter are during teaching and learning activities one of which is in the Pronunciation learning program, the teacher explains the material by writing letters of the alphabet and then the teacher will pronounce the letters one by one and will be followed by students together. This means that the pronunciation of letters together there occurs in group communication, meaning that it is done 
together. The teacher communicates to all students and not just one student. This communication is usually used when the teacher explains the material and when the teacher instructs students to do something. This communication is used so that the message conveyed by the teacher can be received by all students who then students can carry out the instructor's instructions.

The obstacles that occur during the learning communication process are the obstacles originating from the communicator encountered in the implementation of educational communication at SMPN 25 South Solok namely the use of language that can not be understood by students considering students have different cultural backgrounds so that sometimes students who are not accustomed to hearing English, it is difficult to understand the language used by the instructor. The use of English still has constraints in the learning process so that teachers sometimes use more Indonesian, in addition to the different cultures of students it also makes teachers difficult to give examples of cases in delivering material. This is due to the daily life of the Javanese people who will be different from the original community of Dusun Tangah.

Teacher mastery of the media as a whole is quite mastering. However, the limitations of the media become obstacles and reasons that make the process of education communication become hampered. This obstacle is in the form of disruption to the delivery of messages such as the inadequacy of available facilities such as books, teaching aids, besides that SMPN 25, Solok Selatan also does not have a projector so that some material delivery processes are less than optimal. So the obstacle in the channel in delivering material in this school is in the form of limited tools or incomplete media such as projectors because the use of projectors is very helpful in delivering material in the classroom, especially for practical language material rather than using a laptop alone while there are dozens of students.

Feedback is very important, especially in the learning communication process. However, there are still some students who are not too interested in the process of implementing educational communication that they have experienced. They are less enthusiastic because they lack enthusiasm and do not understand the language used by the teacher.

This factor is not solely a result of the teacher, but the students themselves are less optimal and active in the communication process in learning. Most students will be passive when the teacher starts using more English in the learning process.

\section{CONCLUSION}

From the research conducted by researchers, it can be concluded that the learning communication process that takes place at SMPN 25 Solok Selatan involves all components that refer to the communication process namely communicators, messages, channels, communicants, and feedback. Communicators who have the most role in the learning communication process are teachers while students become more communi- 
cants, related to the learning messages that are delivered normally learning messages are in accordance with the prevailing RPP and are also discussed at Solok Selatan MGMP, while the feedback given is direct. Obstacles encountered in the learning communication process include the use of language that is not understood by students, the media in the learning communication process is limited and feedback from some students is lacking because they are not too interested when the process of implementing educational communication they have experienced. They are less enthusiastic because they lack enthusiasm and do not understand the language used by the teacher.

In this study, it is suggested that in the English learning process it is expected that all components involved such as students are expected to be more active in performing roles as communicants and communicators, received with enthusiasm the material delivered by the instructor. I can learn from any student to deepen every opportunity given by the teacher. As for teachers, given the role and function of instructors is very important in the implementation of educational communication, it is expected to carry out its role and function with a maximum view and better understand their duties as communicators in educational communication, especially in the mastery of media and materials.

Associated with obstacles that may arise when the learning process takes place, it is expected that all elements in the communication process can contribute to minimizing it as the teacher tries to motivate students not to be afraid of communicating in English or fellow students who support each other so that no more ridicule when they communicate in English.

\section{REFERENCES}

1. Afrizal. (2015). Metode Penelitian Kualitatif: Sebuah Upaya Mendukung Penggunaan Penelitian Kualitatif Dalam Berbagai Disiplin Ilmu. Edisi Pertama. Jakarta: Rajawali Pers.

2. Akbari, Z. (2015). Current Challenges in Teaching/Learning English for EFL Learners: The Case of Junior High School and High School. Procedia Social and Behavioral Sciences, 199, 394-401.

3. Amjah, D. Y. P. H. (2014). A study of teachers' strategies so develop students' interest towards learning English as a second language. Procedia-Social and Behavioral Sciences, 134, 188-192.

4. Ardianto, E. (2011). Metodologi Penelitian untuk Publik Relation Kuantitatif dan Kualitatif. Bandung: Simbiosa Rekatama Media.

5. Arif, E. (2014). Prilaku komunikasi guru responsif gender. Disertasi. Pascasarjana Institut Pertanian Bogor

6. Cangara, H. (2011). Pengantar Ilmu Komunikasi. Jakarta: Raja Grafindo Persada.

7. Effendy, O. U. (2008). Dinamika Komunikasi. Bandung: Remaja Rosdakarya. 
8. Iriantara, Y., \& Syarifudin, U. (2013). Komunikasi Pendidikan. Bandung: Simbiosa Rekatama Media.

9. Meoleong, L. J. (2011). Metodologi Penelitian Kualitatif. Bandung: Remaja Rosdakarya.

10. Ridwan. (2004). Belajar Mudah Penelitian Untuk Guru, Karyawan dan Penelitian Pemula. Bandung: Alfabeta.

11. Siswandi, H. J. (2006). Meningkatkan keterampilan berkomunikasi melalui metode diskusi panel dalam mata pelajaran Bahasa Indonesia di Sekolah Dasar (penelitian tindakan kelas). Jurnal Pendidikan Penabur, 7(5), 24-35.

12. Sugiyono. (2016). Metode Penelitian Kuantitatif, Kualitatif dan RED. Bandung: Alfabeta

13. Yusof, F. M., \& Halim, H. (2014). Understanding teacher communication skills. Procedia-Social and Behavioral Sciences, 155, 471-476. 